\title{
An Analysis Of Students' Speaking Difficulties at Eighth Grade Smpit At-Taqwa Surabaya
}

\author{
ZhelaMeylinda Clarita, Zhelamc@gmail.com, STKIP BinaInsanMandiri, Surabaya, Indonesia \\ NurHidayat,nurhidayat@stkipbim.ac.id_STKIP BinaInsanMandiri, Surabaya, Indonesia
}

\begin{abstract}
The purpose of this study was to investigate the difficulties of students in speaking English. The researcher used a qualitative descriptive method in this study. The subjects of this study were eighth-grade students A and D SMPIT At-Taqwa 2018/2019 academic year consisting of 40 students and English teachers. Data collection techniques in this study were observation, student questionnaires, and student and teacher interviews. The results of this study indicate that $25 \%$ of students have difficulty speaking English.The efforts made by students and teachers to overcome the challenges in speaking English, such as: taking English tutoring, listening to English songs, practicing reading, writing, and speaking at home and school. They also communicate through social media with foreign citizens, joining English Camp, watching western movies, or change film subtitles with English. Then the solution given by the teacher is an additional lesson hour to support students who felt difficult in speaking English.
\end{abstract}

Keywords: Speaking, Speaking Difficulties, Teaching Speaking.

\section{INTRODUCTION}

Language is a tool to convey messages, information, and ideas from one to other people. Santoso (1990) said that language is a series of sounds produced by a conscious human speech. Moreover, Walija (1990) revealed that language is the most complete and effective communication for expressing opinions to others. Syamsuddin (1986) gave two views. First, writing is a tool used to influence thoughts, feelings, desires, and actions. Second, communication is a symbol of human personality, a symbol of family and country, and a symbol of human thought. All definitions above pointed out that language is a tool to communicate with other people in the world.

English is the most common language used in various countries. The role of English in technology and communication is essential. Along with the development of the current era of globalization, English has developed to be an essential foreign language learned in Indonesia. It has learned since kindergarten. Students must master English both orally and in writing. It consists of the ability to listen, read, speak, and write - these abilities are interrelating with each other. Students will be more confident when they can talk with others correctly. As expressed by Richards \& Renandya(2002) that most students learn English to develop their speaking skills. By speaking, they can express their communication with others.

Students generally have difficulties in learning foreign languages, especially English. However, there are still many students who have a problem in using English in terms, the ability to speak. Oxford (1990) reported that most students have scared to speak English. Leong \& Ahmadi(2017), learners are worried about making mistakes when they are speaking English, and they are afraid of criticism by other students. They feel embarrassed by the attention of other students who directed at the student. Latha \& Ramesh(2012) argue that lack of motivation is one reason for students, not active in-class lessons. It causes students to be passive and reluctant to speak in class. According to Nunan(1999)said that students who lack confidence

108 | IJET| Volume. 9, Issue 1. July 2020 Copyright 2020 ZhelaMeylinda Clarita \& NurHidayat are licensed under Creative Commons AtrributionShareAlike 4.0 International License. 
indeed suffer from fear when communicating.Rivers(1968)students do not have anything to express because the teacher chooses the topic of conversation that is not suitable for students or issues that are not familiar to students. Therefore students are challenging to respond when the teacher invites them to say something in English.

Some researchers have done some studies about the aspects that hinder students' ability to speak. According to Nation (2001) stated that vocabulary is the basis of language skills. The more vocabulary known by students, the students understand the contents of the conversation or writing. Lack of vocabulary is caused students to challenge to understand them. The grammatical problem also becomes a factor that affects students speaking. The students who have difficulty in grammar also feel trouble in speaking English (Oxford, 1990). Another researcher, Liu(2007), confirmed that the ability of students who are low in pronunciation became a students' obstacle to speaking English. Also, Oxford(1990) explained that less confidence caused students afraid to speak English.

The first previous study is a study conducted by Leong \& Ahmadi(2017). This research aims to determine the elements that influence the students' speaking performance. The findings of this research indicated that students with higher motivation and lower discomfort able to speak English fluently and easily and vice versa. However, in this study, the researchers did not explain the specific of the participants' level of their study. The researcher only explains their analysis in a general way without giving specific information about participants' level and specific instruments so that the information that they provided is too general.

Another previous study conducted by Azizah (2016), investigated the speaking obstacles at a senior high level. Eleventh-grade students at MA Al-Muslim NW Tegal became the object of research. Researchers use population techniques to retrieve data. The results of the study were $92.6 \%$ of students had vocabulary limitations, $85.2 \%$ of tension $72.2 \%$ of students were afraid of making mistakes, and $72.2 \%$ of their grammar and $68.5 \%$ of students had restricted fluency. Besides that, students prefer to use Sasak language to communicate.

Even though the previous studies explained the problems of speaking performance, the researcher still wants to investigate the students' difficulties in speaking English at a different level, location and elucidate the elements that cause it more specific with a specific instrument. Therefore, the researcher researched to analyze students' difficulties in speaking English at a junior high level of East Java, Indonesia.

\section{METHOD}

The research method of this study was descriptive qualitative methods because it deals with the phenomenon of the speaking difficulties in a real-life situation that happened to the students while the students are speaking English. This study focused on analyzing the speaking difficulties of eighth grade at SMPIT At-Taqwa Surabaya. The subjects in this research are students SMPIT At-Taqwa Surabaya eighth Grade class 8A, 8D, and the English teachers. The total subjects are two classes, 40 students consisted of 20 females and males. In this study, the researcher used observation, questionnaire sheets, and interviews in data collection techniques. According to toBailey (1994), by observation, the researchers were able to identify ongoing behavior and make notes to the essential activities about it. The researcher was attended in the classroom and gave attention to the students during classroom activities (Cresswell, 1994). The researcher observed the learning of English speaking material in the classroom. Based on Harmer (2011) explained that a questionnaire is a widely used and useful instrument for collecting survey information, providing structured, often numerical data, being able to administer without the presence of the researcher, and often being comparatively straightforward to analyze. In this study, researchers combined open and closed-ended questionnaire. The questionnaire contained 22 questions consisting of 10 open questionnaires

109 | IJET| Volume. 9, Issue 1. July 2020 Copyright 2020 ZhelaMeylinda Clarita \& NurHidayat are licensed under Creative Commons AtrributionShareAlike 4.0 International License. 
and 12 closed-ended questionnaires. The questionnaire was given to students at the junior high school level after the researchers observed students in the class - the questionnaire filled by students according to the real situation.

The interview is rather formal consists of a series of questions designed to elicit a specific answer from the respondent. Both often used to obtain information that compared and contrasted. The researcher interviewed six eighth-grade students after class observation and filling out the questionnaire. The purpose of interviewing students is to know more clearly the causes of difficulties students speak in English and students' effort to cope with the speaking Englishdifficulties. The researcher also interviewed with eighth-grade English teachers. The interview aims to know the method of teaching English at SMPIT At-Taqwa and the efforts that done the teacher to improve students' abilities in English. The results of these interviews can reinforce the fact that students have difficulty speaking and reviewing teaching methods that not properly applied to students.

In analyzing data, researchers used descriptive analysis. In this study, descriptive data analysis included observations, student questionnaires, students, and teacher interviews. While carrying out inspections, the researcher recorded takes note of teaching and learning activities and analyzed the difficulties of students in speaking English in eighth grade. Data obtained from student questionnaires were processed. The researcher calculated the results of the questionnaire using percentages.

\section{RESULT}

\subsection{Result of observation}

In the $8 \mathrm{D}$ classroom, teaching-learning was started with the opening of greetings, checking the attendance of students, and creating the readiness of students to receive learning material. After that, the teacher explained the material that will discuss the core activities. In the core learning activities, the teacher instructed students to create groups of 5 students in each group. Next, the students looked for envelopes containing puzzles in the school area. Students must arrange the puzzle on the paper provided. Students worked with group members to complete the puzzle. The group that compiled the puzzle quickly and correctly given an additional point. After completing the puzzle, students back to their seats. Next, the teacher showed the pictures on the LCD; then the students were shown one by one to describe the image. The teacher responded to students when they were speaking. Then the teacher asked the students to repeat what the teacher described in the pictures.

More than 50\% of students enthusiastically described the image on the screen, although there were passive students also in speaking English. Students who passively speak in class paid less attention to the teacher, and they only focused on their activities. Some students talked to their friends and did not give attention to the teacher. The teacher asked Erika to fill in the blanks based on the image on the screen, but Erika only said, "eehhhmmm..." Then the teacher responds to "Erika, please pay attention to the teacher who is explaining the material; do not talk to other friends."Some of these students showed disinterest in speaking English, for example, a student named Tata. She had to repeat several times imitating pronunciation "she is sad today." Procedure is pronounced (/ sii /is / set / tudei /) which should be (//i: /iz/ sæd / to' deI /).Next, students work on the true/false problem based on the sentence structure.

The questions that have been done by students collected at the teacher's desk. The teacher-reviewed the activities and materials that have been taught at the meeting that day. The teacher also gave homework that must collect at the next meeting. For class 8A, the conditions in the classroom were quite crowded because students talk to other students. Some students also do other activities in the classroom. Therefore most students did not pay attention to teachers who are already in class. The teacher started learning English with greetings. The material

110 | IJET | Volume. 9, Issue 1. July 2020 Copyright 2020 ZhelaMeylinda Clarita \& NurHidayat are licensed under Creative Commons AtrributionShareAlike 4.0 International License. 
delivered on that day was the activity carried out and the activities that have carried out. The teacher said, "Please answer the question, what is Zidan doing?" Then Ahza answered, "Zidan play with the ball." Then the teacher responds to Ahza's answer by giving an example "Okay, for example, Zidan is playing football or Zidan playing football. Choose the first or second example?".Ahza, Rafif, and Arya, choose the second example.

After that, the teacher usedPowerPoint as a learning media. The teacher showed a picture of activity on the screen then says, "who can make a sentence on the picture, please? Raise your hands". Rama raised his hand and answered, "Ehm, last week, I playing football." The teacher responded, "Okay, thank you, Rama, but the activity ends now." Zaidan raised his hand, saying, "Today, I playing football." "Listen and repeat Ustadzah; I'm kicking a ball now." All students repeat the teacher's word, "I'm, kicking a ball now. "

The teacher asked students to create groups of four students in a group. The teacher asks students to make 20 sentences based on activities carried out by school members outside the classroom. After 10 minutes, students went back to the class and compiled the sentence with the group. After completion, the assignment given to the teacher. Then the teacher repeated the material discussion that day and presented the homework that students must complete at the upcoming meeting.

Based on $8 \mathrm{~A}$ and8D class observations that have done, not all students speak English well and correctly. 50\% of students were brave and confident in speaking English in class. Then $25 \%$ of students who can speak English will be shy when talking. $25 \%$ of students were passive in speaking English. These students do other activities in the classroom, so they don't pay attention to the teacher while teaching.

\subsection{The result of the students' questionnaire}

Table 4.1 The result of student's questionnaire

\begin{tabular}{|c|c|c|c|c|}
\hline \multirow{2}{*}{ NO. } & \multirow{2}{*}{ QUESTION } & \multicolumn{3}{|c|}{ ANSWER } \\
\hline & & YES & SOMETIMES & NO \\
\hline 1 & Are you interested in learning English? & $45 \%$ & $33 \%$ & $23 \%$ \\
\hline \multirow{3}{*}{2} & \multirow{3}{*}{ Where did you first learn English? } & \multicolumn{3}{|c|}{ Kindergarten $58 \%$} \\
\hline & & \multicolumn{3}{|c|}{ Primary school $33 \%$} \\
\hline & & \multicolumn{3}{|c|}{ Another answer $10 \%$} \\
\hline 3 & Do you often speak English at home? & $35 \%$ & $40 \%$ & $25 \%$ \\
\hline \multirow{3}{*}{4} & \multirow{3}{*}{ Who do you speak English at home with? } & \multicolumn{3}{|c|}{ Parents $65 \%$} \\
\hline & & \multicolumn{3}{|c|}{ Brother / Sister 13\% } \\
\hline & & \multicolumn{3}{|c|}{ Another answer $23 \%$} \\
\hline \multirow{3}{*}{5} & \multirow{3}{*}{ How often do you speak English at home? } & \multicolumn{3}{|c|}{ Very often $33 \%$} \\
\hline & & \multicolumn{3}{|c|}{ Sometimes $45 \%$} \\
\hline & & \multicolumn{3}{|c|}{ Never $23 \%$} \\
\hline 6 & Do you often speak English at school? & $35 \%$ & $65 \%$ & $0 \%$ \\
\hline \multirow{3}{*}{7} & \multirow{3}{*}{ Who do you speak English at school? } & \multicolumn{3}{|c|}{ Teacher $55 \%$} \\
\hline & & \multicolumn{3}{|c|}{ Friend $25 \%$} \\
\hline & & \multicolumn{3}{|c|}{ Teacher and Friend $18 \%$} \\
\hline \multirow{3}{*}{8} & \multirow{3}{*}{ How often do you speak English at school? } & \multicolumn{3}{|c|}{ Everyday $25 \%$} \\
\hline & & \multicolumn{3}{|c|}{ During English lessons only $60 \%$} \\
\hline & & \multicolumn{3}{|c|}{ Rarely $15 \%$} \\
\hline 9 & If answers number 3 and 6 are not, then what & \multicolumn{3}{|c|}{ Indonesian language $40 \%$} \\
\hline
\end{tabular}

111 | IJET $\mid$ Volume. 9, Issue 1. July 2020 Copyright 2020 ZhelaMeylinda Clarita \& NurHidayat are licensed under Creative Commons AtrributionShareAlike 4.0 International License. 


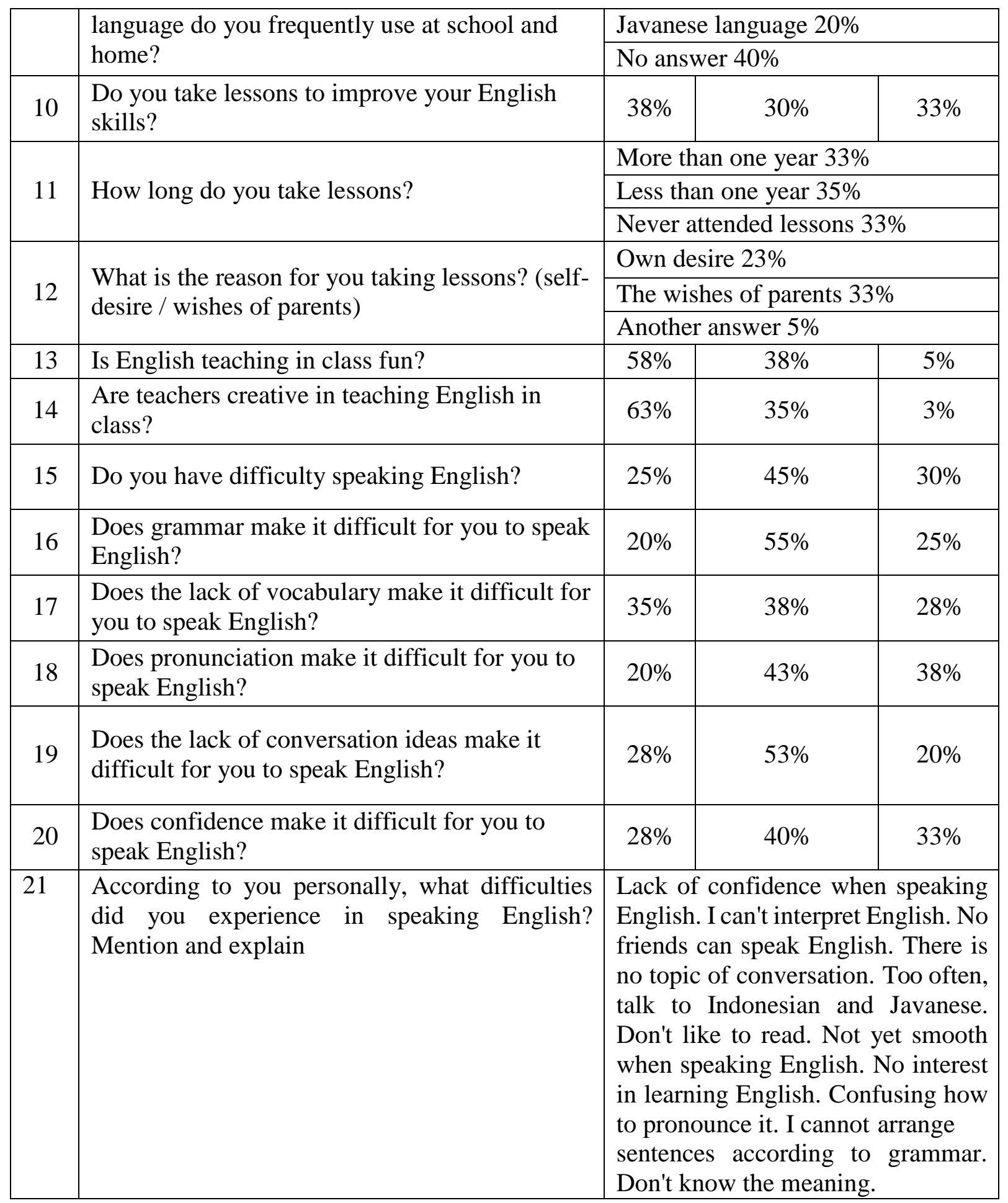

112 | IJET| Volume. 9, Issue 1. July 2020 Copyright 2020 ZhelaMeylinda Clarita \& NurHidayat are licensed under Creative Commons AtrributionShareAlike 4.0 International License. 


\begin{tabular}{|l|l|l|}
\hline 22 & What efforts have you made to deal with your \\
difficulties in speaking English? & $\begin{array}{l}\text { Take English lessons. Listen to } \\
\text { English songs. Practice reading, } \\
\text { writing, and speaking English at all } \\
\text { times. Communicate via social } \\
\text { media with foreign citizens. Attend } \\
\text { English camp activities at school. I } \\
\text { was watching western movies. I } \\
\text { went to the English village in Pare } \\
\text { during school holidays. Participate } \\
\text { in the conversation competition. } \\
\text { Reply to short messages in English. } \\
\text { Make a post using English. }\end{array}$ \\
\hline
\end{tabular}

\subsection{The result of students' interview class 8A on April 15, 2019}

Name of respondents:Riffan, Zidan, and Aksa.

Q: Do you often speak English at home?

A: Riffan: Never.

Zidan: No.

Aksa: Never.

Q: What language do you use when communicating at home?

A: Riffan: Indonesian language.

Zidan: Javanese language.

Aksa: Indonesian language or Javanese language.

Q: Do you take lessons to improve your English skills?

A: Riffan: Yes.

Zidan: Yes.

Aksa: Yes.

Q: How long have you been taking lessons?

A: Riffan: One year, since the 8th grade of the first semester until now.

Zidan: One year during elementary school, grade 4.

Aksa: 5 years are from grade 1 elementary to grade 5 .

Q: What is your reason for taking lessons?

A: Riffan: Want to learn English and be told by parents.

Zidan: Want to be able to learn English.

Aksa: Asked by parents, actually don't want to.

Q: Do you have difficulty speaking English?

A: Riffan: Yes, it's complicated.

Zidan: Yes, it's complicated.

Aksa: Yes, it's complicated.

Q: According to you personally, what difficulties did you experience in speaking English?

Please mention and explain.

A: Riffan: Know the basics but can't learn English. When I learn English in class, then I can't speak. I use Indonesian.

Zidan: I can, but I don't know the meaning. The teacher's writing read, but I don't know the meaning.

Aksa: I do not know what that means.

\subsection{The result of students' interview class $8 D$}

Name of respondents: Aliyah, Nerissa, and Erika 
Q: Do you often speak English at home?

A: Aliyah: I'm usually told by my dad to practice speaking, but that's it. I am used to speaking Indonesian. I can speak English, but I'm embarrassed. Usually speaking Indonesian, suddenly speaking English became a bit stiff.

Nerissa: No.

Erika: Ehmmno.

Q: Do you take lessons to improve your English skills?

A: Aliyah: Yes, I joined the tutoring, first-class 4 to grade 5 at EF, but because the place was far away, I went out. Now, move on to ELC starting in class 8.

Nerissa: Previously, at the beginning of semester one at the ELC, now it has been released because I entered into neutrons for preparation for class 9 .

Erika: Never at all.

Q: How long have you been taking lessons?

A: Aliyah: Two years.

Nerissa: six month

Erika: -

Q: What is your reason for taking lessons?

A: Aliyah: It asked by my parents.

Nerissa: It asked by my parents.

Erika: -

Q: Do you have difficulty speaking English?

A: Aliyah: Yes.

Nerissa: Yes

Erika: Yes, of course

Q: According to you personally, what difficulties did you experience in speaking English?

Please mention and explain.

A: Aliyah: For example, if there is a new vocabulary, I don't know the meaning, and I'm embarrassed when I speak English.

Nerissa: I am embarrassed when I speak English.

Erika: Yeah, because I'm not used to speaking English.

Q: What have you done to improve English speaking?

A:Aliyah: I used to listen to western songs but now prefer Korean songs. But when I look at Korean dramas, the subtitles use English, so we think a little what that means.

Nerissa: Sometimes, I listen to western songs.

Erika: At school, I also held an English camp. Grade 7 in Pare, during 8th grade in Trawas. Pare is like a class lesson. But yesterday there were many trees in Trawas, and they told me what trees were there - then I taught me how to cook and make drinks. The instructions are in English, but when we talk to friends, we don't use English.

\subsection{The result of teacher interview}

In a week, there were four hours of English lessons consisting of 35 minutes per hour. The teacher should provide a lesson plan for each meeting - the English learning handbook made by the English teacher coordinator. The teacher used PowerPoint and physical printouts as learning media. The learning method used in speaking is listening and repeat, conversations, and telling stories. Moreover, students like speaking material packaged in games or discussions with friends.

In evaluating students speaking, the teacher reported the learning material as far as has been conveyed to students and obstacles in the classroom during learning. The obstacles became a challenge for teachers to create fun learning. The obstacle faced by the English teacher 
was the students' speaking ability, heterogeneity, and motivation. The English teacher said that students had difficulty speaking, such as lack of confidence in speaking, fear of being wrong, and not being used to talk in English. However, the teacher has made an effort to overcome the difficulties of students in speaking English. She gave additional lesson hours for students who have hardship in speaking English. Also, the English teacher asked the students to help each other. She asked them to learn in groups which consisted of heterogeneous students.

The findings above that the students who felt difficulty in speaking English were $25 \%$, the students who felt sometimes have trouble speaking English were 45\%. While students have no problem speaking English as much as $30 \% .45 \%$ of students were interested in learning English, 33\% of students sometimes interested in learning English, and 23\% of students were not interested in learning English. It affected the learning and teaching process in the classroom. Students who were involved in learning English positively actively answering questions, always speak English and have more curiosity in new material taught. Conversely, students who were passive in the process of learning and teaching in class are students who are not interested in learning English. According to Harmer (2011), a student who is excited and enthusiastic does not generally exhibit problem behavior. Similarly, Latha \& Ramesh(2012), described that lack of motivation influenced students' intensity in speaking English.

The students with speaking difficulty in terms of grammar were $20 \%$. In comparison, students who sometimes feel pain in speaking English in terms of grammar were 55\%, other students have no pain in terms of grammar were $25 \%$ of students. Fromkin et al. (2014), grammar is a combination of words and rules that produce new sentences. Grammar is needed by the speaker to arrange good sentences in the conversation.

The students who do not speak English at home and in the classroom choose to use the Indonesian language were $40 \%$ of students, $20 \%$ of students using the Javanese language, and other students do not answer where $40 \%$ of students. According toUr(1996), inhibition, lack of local knowledge, low or uneven participation, and mother tongue use are students' speaking difficulties. Harmer (2011) points out that the reason students use their mother tongue is when students discuss unknown topics so that students use their mother tongue. Besides, the students felt natural using their mother tongue. The students who have hardship in speaking English in terms of confidence were $28 \%$, students who argue rarely have difficulty speaking English in terms of confidence were $40 \%$, and students have no difficulty speaking English in terms of confidence were 33\%. According to Nadzirotunnuha(2017) states that a lack of confidence occurs when the other person starts not to understand the conversation. In these conditions, students prefer to be quiet and not continue the conversation.

Students with speaking hardship because of lack of vocabulary were $35 \%$ of students, $38 \%$ of students sometimes have difficulty speaking English due to lack of vocabulary. In comparison, $28 \%$ of students have no difficulty speaking English due to a lack of vocabulary. Oxford (1990) described that one of the aspects that made students difficult in speaking English was lack of vocabulary.20\% of students have difficulty speaking English in terms of pronunciation; $43 \%$ of students sometimes choose to have difficulty speaking English in terms of pronunciation. In contrast, students who have no difficulty speaking English in terms of pronunciation were $38 \%$ of students. Kelly (2000) said that the pronunciation problem caused by the use of inaccurate pressure and intonation in conversation. Also, Liu (2007) believed that the lack of pronunciation could be an obstacle for students to speak English. There were 28\% of students have difficulty in speaking English. Their problem is in terms of no idea of conversation. Students who argue sometimes have trouble speaking English in terms of no concept of conversation were 53\%, and students who have no trouble speaking English in terms of no ideas for communication were $20 \%$ of students. Rivers (1968) stated that students who do not have an idea would hinder students' ability to express their feeling.

115 | IJET| Volume. 9, Issue 1. July 2020 Copyright 2020 ZhelaMeylinda Clarita \& NurHidayat are licensed under Creative Commons AtrributionShareAlike 4.0 International License. 


\section{CONCLUSIONS}

Based on the results above, I found that the aspects that influence the students' difficulty in speaking were: first language (mother tongue), having no idea, lacking grammar, pronunciation, vocabulary, and confidence. Some efforts have been made such as: taking additional English lessons, listening English songs, practicing reading, writing and speaking English, communicating with foreign citizens via social media, joining English camp activities, watching western movies, going to the English village in Pare during school holidays, Participating in the conversation competition, replying to short messages in English and posting used English.

Hopefully, this research used as a guide or reference for researching and speaking. Other researchers expected to do the same study with different populations and techniques so that the results are more maximal. Further research also emphasizes the analysis of classroom teaching techniques. 


\section{REFERENCES}

Azizah, I. (2016). An analysis of students' difficulties in speaking English: A case study at eleventh-grade students of MA Al Muslimun NW Tegal in the academic Year 2015-2016. Thesis. English Education Program Language and Art Department Faculty of Teacher Training and Education.

Bailey, K. (1994). Methods of Social Research. New York: The Free Press.

Cresswell, J. D. (1994). Research Design; Qualitative \& Quantitative Approaches. SAGE Publications.

Fromkin, V., Rodman, R., \& Nina Hyams. (2014). An Introduction to Language (10th ed.). Wadsworth, Cengage Learning.

Harmer, J. (2011). The Practice Of English Language Teaching (3rd ed.). Cambridge,Uk: Pearson Longman.

Kelly, G. (2000). How to Teach Pronunciation. Edinburg: Pearson Education Limited.

Latha, B. M., \& Ramesh, P. (2012). Teaching English as A Second Language: Factors Affecting Learning Speaking Skills. International Journal of Engineering Research \& Technology (IJERT).

Leong, L. M., \& Ahmadi, S. M. (2017). An analysis of factors influencing learners' English speaking skills (University Sains Malaysia).

Liu, M. (2007). In Oral English Classrooms: A Case Study In China. Indonesian Journal of English Language Teaching Volume, 3, 119-121.

Nadzirotunnuha, A. (2017). The Analysis of students' Problems On Speaking Skill At SMP Islam Darussalam Dongko. English Language Teaching Program Faculty of Education and Teacher Training.

Nation, I. S. P. (2001). Learning vocabulary in another language. Cambridge University Press.

Nunan, D. (1999). Second Language Teaching \& Learning. Boston: Heinle\&Heinle Publisher.

Oxford, R. L. (1990). Language Learning Strategies: What every teacher should know. House Publishers.

Richards, J. C., \& Renandya, W. A. (2002). Methodology in Language Teaching: An anthology of Current Practice. Cambridge University Press.

Rivers, W. (1968). Teaching Foreign Language Skills. Harlow, United Kingdom: University of Chicago Press.

Santoso, K. B. (1990). Problematika Bahasa Indonesia. Indonesia: Angkasa.

Syamsuddin, A. (1986). Sanggar Bahasa Indonesia. Indonesia: Universitas Terbuka Jakarta.

Ur P. (1996). A course in Language Teaching: Practice and Theory. New York: Cambridge University Press.

Walija. (1990). Bahasa Indonesia dalam Perbincangan. Indonesia: IKIP Muhammadiyah Jakarta Press. 